CHAPTER 32

\title{
The Palaeoethnobotanical Evidence
}

\author{
Anita Radini, Alison McQuilkin, Emma Tong and Nicky Milner
}

\section{Introduction}

Understanding how plants might have been used for food, fuel and building materials in the past can be very challenging, especially for prehistoric hunter-gatherers who trod lightly on the land and as a consequence left little trace of their presence behind them (Mason and Hather 2002). Indeed, very little evidence for plant use or burning was found in the original Star Carr excavations. Clark noted six shallow lenses of charcoal, two of which appear to be associated with pebbles; however, all that could be said was that fires had left little trace except a shallow lens of charcoal and that even where there were settings of stone pebbles associated with them there was no evidence of prolonged use (Clark 1954, 12, Figure 7).

Further investigation of burning was undertaken following the 1980s excavations: here Hather (1998) examined charcoal taken from monoliths sampled from the wetland, which was carried out in order to examine whether vegetation burning had happened in situ, locally or was a result of distant fires. He found that there was no evidence for domestic wood burning from the adjacent occupation and that the wood charcoal was largely derived from the burning of the reed beds.

In the recent excavations, the wetland deposits have revealed important information on ancient woodworking techniques, wooden structures, wooden artefacts and the use of bark and fungi (see Chapters 6, 28, 29, 30 and 31). In addition, macrofossils and pollen have been used to reconstruct the past environment (Chapter 19). However, we do not have macrofossil data which clearly pertains to human activity such as food processing; and indeed, even if people were dumping hearth waste into the lake, it is likely that most of it would have floated away. The only evidence that has been found is some discrete charcoal patches and these have been bulk sampled and investigated in the lab.

In terms of the dryland, we have looked carefully for evidence of plant-related activities in the form of charred plant remains, e.g. evidence of plants in the diet as well as choices of wood used. However, as with many Mesolithic dryland sites, there are problems with preservation and truncation: at Star Carr very little undisturbed buried soil is present and hearths are not visible. Despite these limitations, there are a number of areas on the dryland which have provided contexts with higher potential, such as the structures and the area of occupation spread around the central structure (see Chapter 20), and samples for flotation have been taken from these deposits as well as spot sampling across the site (see Chapter 15).

\section{How to cite this book chapter:}

Radini, A., McQuilkin, A., Tong, E. and Milner, N. 2018. The Palaeoethnobotanical Evidence. In: Milner, N., Conneller, C. and Taylor, B. (eds.) Star Carr Volume 2: Studies in Technology, Subsistence and Environment, pp. 447-460. York: White Rose University Press. DOI: https://doi.org/10.22599/book2.r. Licence: CC BY-NC 4.0 
In addition, the micromorphology revealed that the hollow of the eastern structure was comprised largely of organic rich matter, and it was suggested that plant material, such as reeds, made a substantial contribution to sediments in the feature, having perhaps been used for flooring (Chapter 5; Conneller et al. 2012). It was therefore felt that phytolithology was a promising technique to employ (Dimbleby 1978; Rovner 1983). This chapter deals first with the charred plant macro-remains and then the phytolith study in order to examine the palaeoethnobotanical interactions at Star Carr.

\section{The charred plant macro-remains}

\section{Sampling}

In order to sample all archaeological features with strong potential for the recovery of charred remains, a sampling strategy and flotation programme was adopted following Historic England guidelines (Campbell et al. 2011). In total 411 bulk samples were taken for flotation. In 2008, the majority of grid squares in trench SC23 were sampled (Figure 32.1), with higher numbers of samples being taken from around the eastern structure. The lack of data from the vast majority of the trench (except from the structure) meant that in later years we tended to focus on areas with a higher likelihood of success such as features (see Chapter 15 for sampling methods). In addition, a total of 172 charcoal fragments from 80 locations were sampled by hand during the excavation. These were normally collected because they were relatively large pieces.

Importantly, six discrete charcoal dumps (samples 13, 1902, 1903, 1904, 1905, 3585) were found in the waterlogged deposits, either at the base of the wood peat or in the reed peat, and these are assumed to be similar to those discovered by Clark $(1954,12)$ (Figure 32.1). These were cleaned, photographed and bulk sampled (Figure 32.2). In addition, samples were taken from: a large, sub-circular spread of charcoal (318) up to $7 \mathrm{~m}$ in diameter and 20-30 mm thick, which was recorded from the reed peat just above part of the central platform; an area of burning between Clark's trenches (sample 1878) and flint cache AC8 (see Chapter 8) (Figures 31.1 and 32.2).

\section{Methods}

Soil samples that were less than four litres in volume were sieved using the bucket flotation method to maximise the recovery of remains and larger samples were sieved in a tank (see Chapter 15). All fractions were scanned and sorted for analysis. The plant macrofossils were examined under a stereomicroscope at magnifications of between $\times 10$ to $\times 40$. All charcoal fragments above $1 \mathrm{~mm}$ were grouped according to their morphology/type. The fragments of each type were then fractured using an acupuncture needle to obtain the correct sections that allow viewing of anatomical features needed for their identification. The identification and nomenclature that follow are as specified in Chapter 15.

For the purpose of this study, all remains that could be identified were counted. Where this was not possible, because the remains were too small, the overall weight was recorded. Wherever possible, estimated age was also noted. Although most charcoal fragments were too small to be identified, and many features of the growth anatomy were not visible, a number of characteristics could be recorded which provided further details concerning the environment from which the wood was sourced, e.g. the presence of hyphal growth in the charcoal which indicates the use of dead wood (Asouti and Austin 2005; Scott 2010; Théry-Parisot et al. 2010). However, it must be stressed that fragments of charcoal this size or smaller (in the range of micro-charcoal) can be of windblown origin or even residual in soil and are therefore difficult to correctly interpret for analysis.

\section{Results}

\section{Introduction}

Un-charred seeds from modern arable weeds along with worm egg capsules were present in many samples, suggesting a degree of soil disturbance (this modern material was omitted from the analysis). No charred seeds 

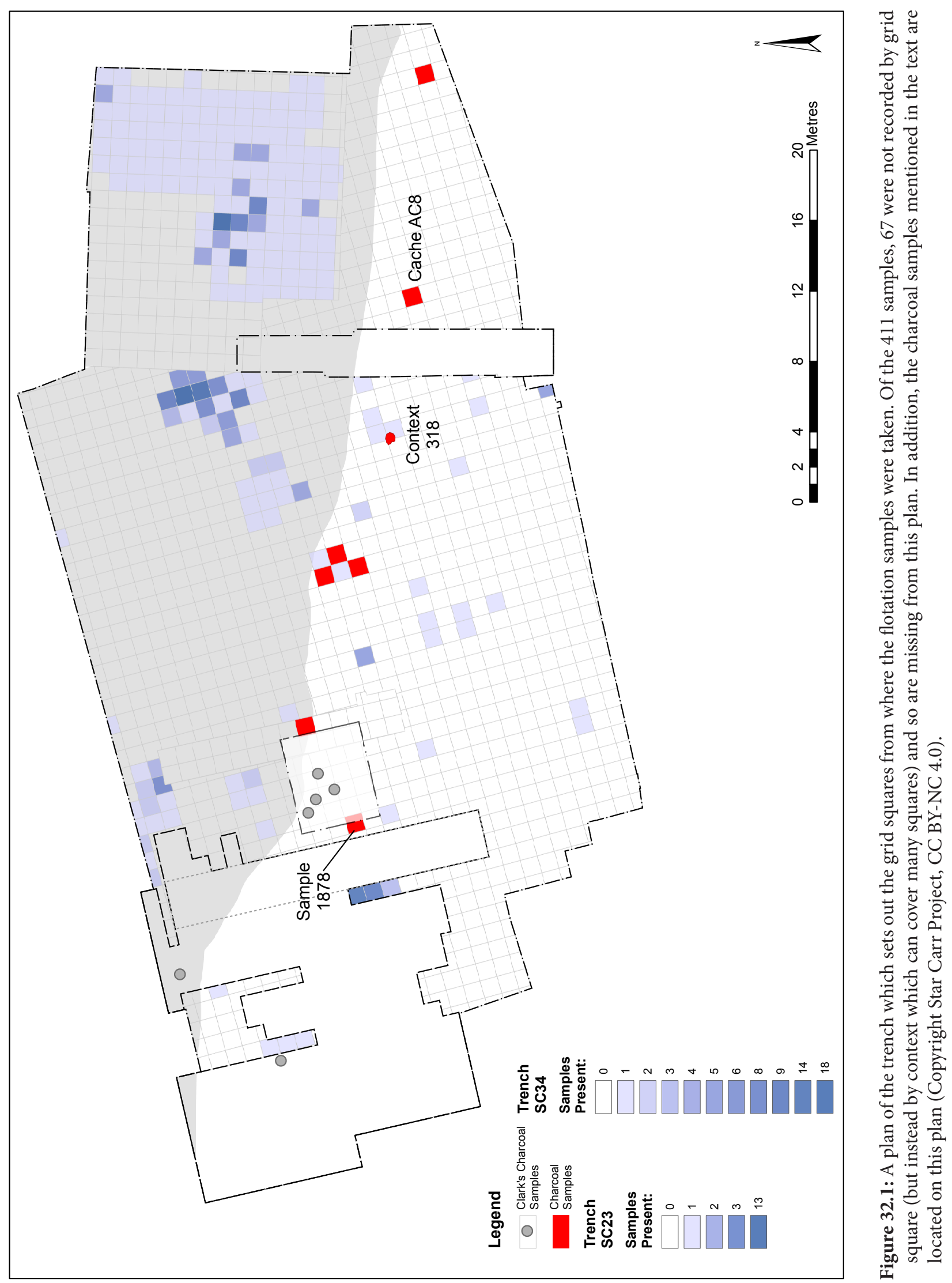

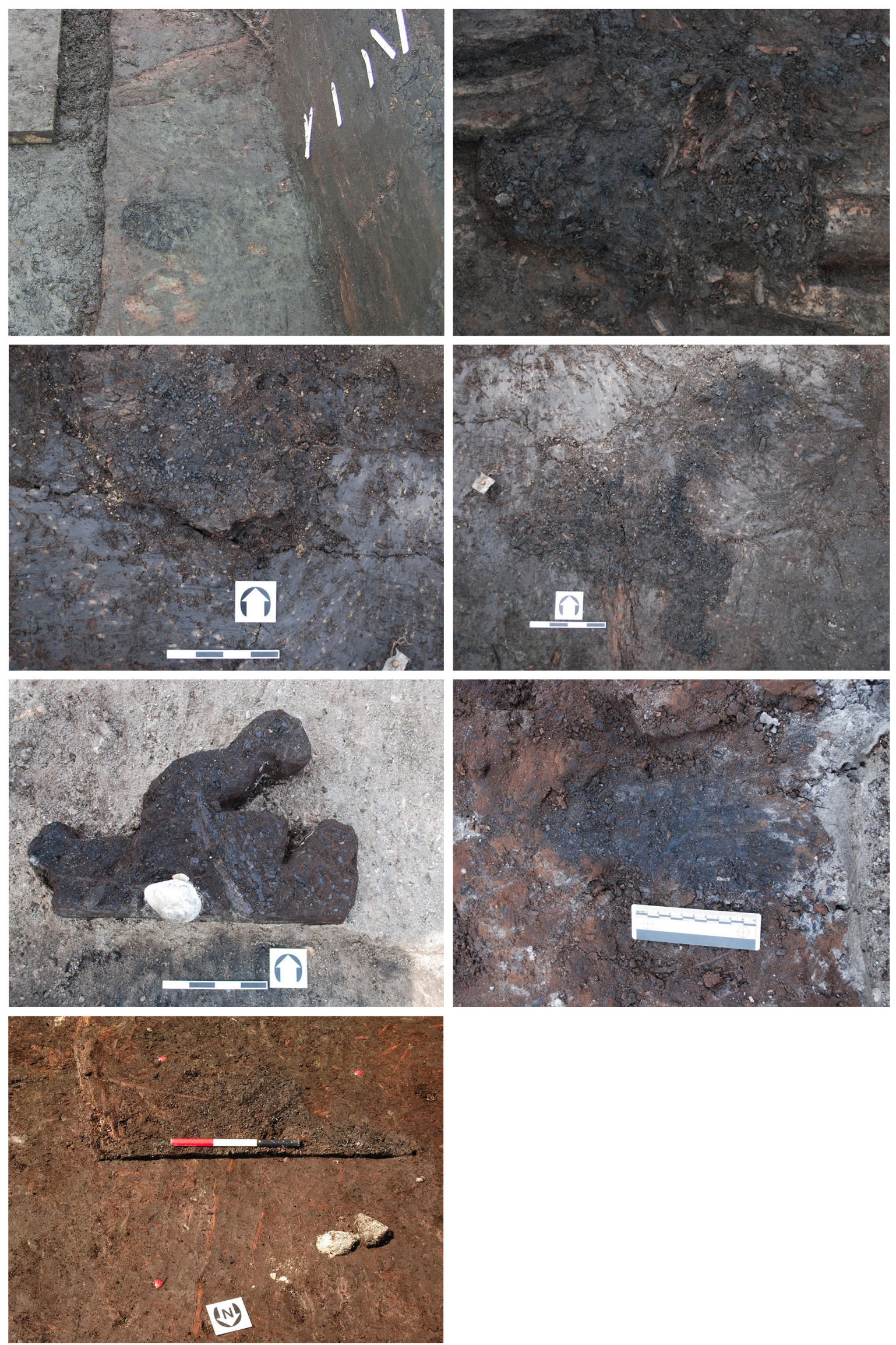
were recovered, and the majority of samples yielded less than 1 gram of charcoal in total weight and consisted of very small fragments (often below $0.5 \mathrm{~mm}$ ), which made identification impossible.

Despite the fact that charcoal is commonly thought to be very robust, even at a microscopic scale, many charcoal fragments exhibited severe deterioration issues due to the formation of pyrite within their structure, as well as iron/manganese patinas, a condition also observed on other remains (see Chapter 22). The formation of pyrite has, at least in part, had the effect of causing fragmentation, and consequently may be the reason for a lack of charcoal retrieved from a considerable number of samples. Furthermore, the growth of pyrite and the deposition of iron and manganese on important features of the charcoal meant that identification was often impossible.

\section{Hand-picked charcoal}

All 172 fragments of charcoal that had been hand-picked on site could be identified to species (Figure 32.3). However, these samples are subject to collection biases and are not necessarily representative of the use of wood

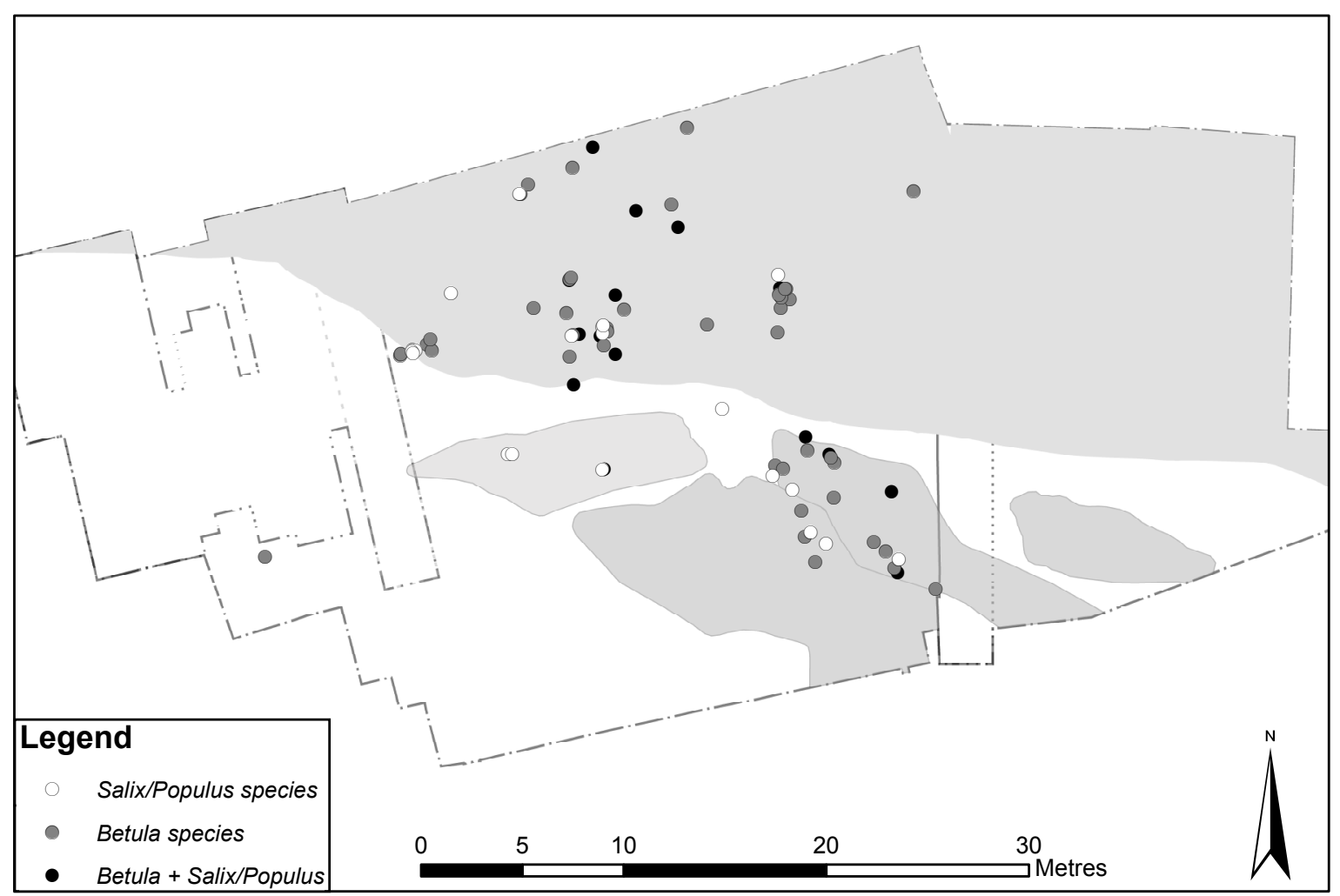

Figure 32.3: Plot of handpicked charcoal samples (Copyright Star Carr Project, CC BY-NC 4.0).

Figure 32.2 (page 450): (top left) sample 13, discrete charcoal patch, in reed peat in trench SC24 (i.e. close to Clark's charcoal patches); (top right) sample 1902 in reed peat; (second row left) sample 1903, in oxidised peat on lake edge; (second row right) sample 1904 just above peat/mineral sediment interface; (third row left) sample 1905 within wood peat (310), on interface with mineral sediment; (third row right) sample 3585 found at base of peat (302) on lake edge; (bottom) part of spread of charcoal (318), half sectioned, and found close to two burnt stones (Copyright Star Carr Project, CC BY-NC 4.0). 
across site. The identification was conducted in order to see whether different species were present and if there was any patterning across site. The results show that $67 \%$ belonged to birch (Betula spp.), and in 20 cases both birch (Betula spp.) and willow/poplar (Salix/Populus) were retrieved from the same location. Whilst Betula spp. seems more abundant, biases in the survival of charcoal as well as biases of collection could have caused this patterning.

\section{Charcoal recovered from flotation}

Only 31 of the flotation samples from clearly defined contexts contained charcoal remains that were of a sufficient size $(2-4 \mathrm{~mm})$ to be identifiable. All identified fragments belonged to birch (Betula spp.) or willow/poplar (Salix/Populus) and no other wood taxa were found to be present in the charcoal assemblage. The vast majority of these samples $(n=23)$ come from the area north of Clark's area, one sample comes from the flint cache found in square AC8 (see Chapter 8), one comes from Clark's area (within the baulk) and five come from the discrete charcoal patches (samples 13, 1902, 1903, 1904 and 1905). Among these, only seven samples contained 100 or more pieces of charcoal which allowed wood taxa composition and some growth details to be retrieved. The data must be considered with caution due not only to the formation processes relating to composition and proportions of wood taxa but also to differing responses to the burning of distinct wood types.

The area to the north of Clark's cutting III (the bead manufacturing area, Chapter 33) contained large quantities of birch bark rolls (Chapter 30), ephemeral spreads of burning and two beads in situ. Some large chunks of burnt wood were also found in situ. This is the clearest evidence for a possible hearth across the whole site. Samples were taken through the profile in both the wood peat and reed peat. In all but two samples, only a few fragments of charcoal (less than 15) could be identified to species. Nine of the samples produced only willow/ poplar charcoal, three produced only birch charcoal and the rest produced a mixture. The only sample with a fairly large quantity of identifiable charcoal was sample 3467, which consisted of 86 fragments of charcoal: half were birch and half were willow/poplar. Overall, the evidence shows that both birch and willow/poplar are being burnt in this location, and the mix of species occurs at all levels.

A sample containing 1819 fragments of charcoal was retrieved in 2013 (sample 1878) from the edge of trench 34 , by Clark's baulk. It produced almost equal quantities of both birch $(\mathrm{n}=945: 52 \%)$ and willow/poplar $(\mathrm{n}=874$ : $48 \%$ ) and contained wood of different ages. The presence of some fungal growth still visible in some of the birch charcoal suggests dead wood was collected and burnt. Such debris suggests a pattern of deliberate selection and while taphonomic processes are not clear, the nature of the assemblage is indicative of the deliberate disposal of the remains of a fire(s).

The flint cache found in square AC8 was a tightly grouped cache of flint most of which came from one nodule. The sediment from within the flint was sampled (sample 3610), though at the time it was hypothesised that the sediment might have been intrusive because there were a lot of voids between the flints: it has since been suggested that the flints may have been contained in a bag, and therefore it is more likely that the charcoal has filtered down with the sediment from above. The sample consisted of small fragments of charcoal: 27 were large enough to identify to species showing that they were a near equal mixture of birch $(n=14)$ and willow/poplar $(n=13)$.

The seven discrete charcoal patches also showed a mix of birch and willow/poplar. Sample 13 consisted of only a few fragments which could be identified. The other samples consisted of several hundred fragments of birch and willow/poplar charcoal all of which showed a mix (Table 32.1). In all of the samples the wood appears to have been gathered from trees of different ages, as well as from different parts of the tree, e.g. the trunk and branches. This demonstrates that each charcoal spread was made up of more than one piece of wood. In addition, a few fragments of birch charcoal provide evidence of hyphal growth, indicating that dead wood was also chosen. These patches of charcoal are very difficult to interpret. Ordinarily, this would be interpreted as representing the remains of a fire; however, some of them (such as sample 13) occur in small, very discrete patches (Figure 32.2), in some cases in the wetland and therefore from their morphology and in many cases their context, they could not have been burnt in situ. The only explanation seems to be that charcoal was perhaps put into a small container, perhaps a bag, and deposited at the edge of the lake.

Finally, a total of 13 samples from post holes and the central hollow of the eastern structure produced a very small amount of charcoal, for the most part below $0.5 \mathrm{~mm}$ in size (Table 32.2). These results show no clear patterning: here again birch and willow/poplar were the only species that could be identified, although the latter was more common. Although the fragments were very small, a number were selected for radiocarbon analysis (Chapter 17). 


\begin{tabular}{|c|c|c|c|}
\hline Sample & Context & Betula sp. & Salix/Populus \\
\hline 13 & Within reed peat $(312=84)$ & $\begin{array}{r}3 \\
(20 \%)\end{array}$ & $\begin{array}{r}12 \\
(80 \%)\end{array}$ \\
\hline 1902 & $\begin{array}{l}\text { Within reed peat } \\
(312)\end{array}$ & $\begin{array}{r}734 \\
(62 \%) \\
\end{array}$ & $\begin{array}{r}453 \\
(38 \%) \\
\end{array}$ \\
\hline 1903 & $\begin{array}{l}\text { Base of oxidised reed peat (312), on lake edge, at interface with basal } \\
\text { mineral sediment (308) }\end{array}$ & $\begin{array}{r}321 \\
(46 \%) \\
\end{array}$ & $\begin{array}{r}375 \\
(54 \%) \\
\end{array}$ \\
\hline 1904 & $\begin{array}{l}\text { Base of oxidised reed peat (312), on lake edge, at interface with basal } \\
\text { mineral sediment (308) }\end{array}$ & $\begin{array}{r}865 \\
(71 \%)\end{array}$ & $\begin{array}{r}345 \\
(29 \%)\end{array}$ \\
\hline 1905 & Within wood peat (310), on interface with basal mineral sediment (308) & $\begin{array}{r}356 \\
(43 \%) \\
\end{array}$ & $\begin{array}{r}463 \\
(57 \%) \\
\end{array}$ \\
\hline 3585 & $\begin{array}{l}\text { Basal peat on lake edge } \\
(302)\end{array}$ & $\begin{array}{r}32 \\
(68 \%) \\
\end{array}$ & $\begin{array}{r}15 \\
(32 \%) \\
\end{array}$ \\
\hline NA & Charcoal spread (318) (sampled for radiocarbon dating) & 0 & $\begin{array}{r}2 \\
(100 \%)\end{array}$ \\
\hline
\end{tabular}

Table 32.1: Data for the seven discrete charcoal patches.

\begin{tabular}{|r|r|l|l|r|}
\hline Fill & Cut & Feature & Selected Charcoal ID & $\begin{array}{l}\text { Number of } \\
\text { Fragments }\end{array}$ \\
\hline 149 & 164 & hollow of eastern structure & $\begin{array}{l}\text { Birch (Betula sp.) and Willow/Poplar } \\
\text { (Salix/Populus) }\end{array}$ & 8 \\
\hline 178 & 177 & post hole of eastern structure & Willow/Poplar (Salix/Populus) & 2 \\
\hline 182 & 181 & post hole of eastern structure & Willow/Poplar (Salix/Populus) & 2 \\
\hline 325 & 330 & hollow in central structure (upper fill) & Willow/Poplar (Salix/Populus) & 2 \\
\hline 331 & 330 & hollow in central structure (lower fill) & Birch (Betula sp.) & 3 \\
\hline 339 & 338 & $\begin{array}{l}\text { post hole on western arc round hollow of the } \\
\text { central structure }\end{array}$ & Willow/Poplar (Salix/Populus) & 2 \\
\hline 343 & 342 & $\begin{array}{l}\text { post hole on western arc round hollow of the } \\
\text { central structure }\end{array}$ & Willow/Poplar (Salix/Populus) & 4 \\
\hline 405 & 411 & $\begin{array}{l}\text { grey lens associated with burnt debitage } \\
\text { around western structure }\end{array}$ & Birch (Betula sp.) & 4 \\
\hline 507 & 507 & possible post hole around western structure & Willow/Poplar (Salix/Populus) & 2 \\
\hline 508 & 508 & possible post hole around western structure & Willow/Poplar (Salix/Populus) & 2 \\
\hline 503 & 512 & possible post hole around western structure & Willow/Poplar (Salix/Populus) & 5 \\
\hline 506 & 514 & post hole around western structure & Willow/Poplar (Salix/Populus) & \\
\hline 509 & 515 & possible post hole around western structure & Birch (Betula sp.) & \\
\hline
\end{tabular}

Table 32.2: Fragments of charcoal that could be identified for $\mathrm{C} 14$ analysis. 


\section{Phytoliths and micro-charcoal}

\section{Introduction}

Phytoliths are microscopic silica structures formed when soluble silica or monosilicic acid is taken up by the vascular system of plants during transpiration and are deposited within the cells or spaces surrounding the cells (Pearsall 1982; Rovner 1983; Pearsall 2010; Weiner 2010). The shapes, or morphotypes, of these structures vary, not only among the individual parts of the plant such as the roots, stems, leaves and inflorescences, but in some cases also specific to families, genera or species (Pearsall 1982; Rovner 1983; Piperno 2006; Pearsall 2010). When the plant decomposes, the silica particles are generally deposited into the soil where they are known to survive in most conditions for very long periods of time (Weiner 2010). Although phytolith studies have been minimally applied to archaeological sites in Britain (Powers 1992; Powers-Jones 1994), phytolith analysis has successfully been employed on sites throughout the world for the purpose of identifying and characterising evidence of past human occupation, i.e. hearths and bedding material from prehistoric caves (Albert et al. 1999; Karkanas 2002; Madella et al. 2002; Albert et al. 2012), boundary limits of an Iron Age settlement (Cabanes et al. 2012) and storage and food processing areas located in a Neolithic domestic structure (Tsartsidou et al. 2009).

\section{Method}

During the 2008 excavation bulk soil samples were collected from within the footprint of the structure and across other areas of the site (Figure 32.4). According to Pearsall (1982), this method of collecting soil samples provides better comparative results between spatially distinct areas of a site, such as with the floors of

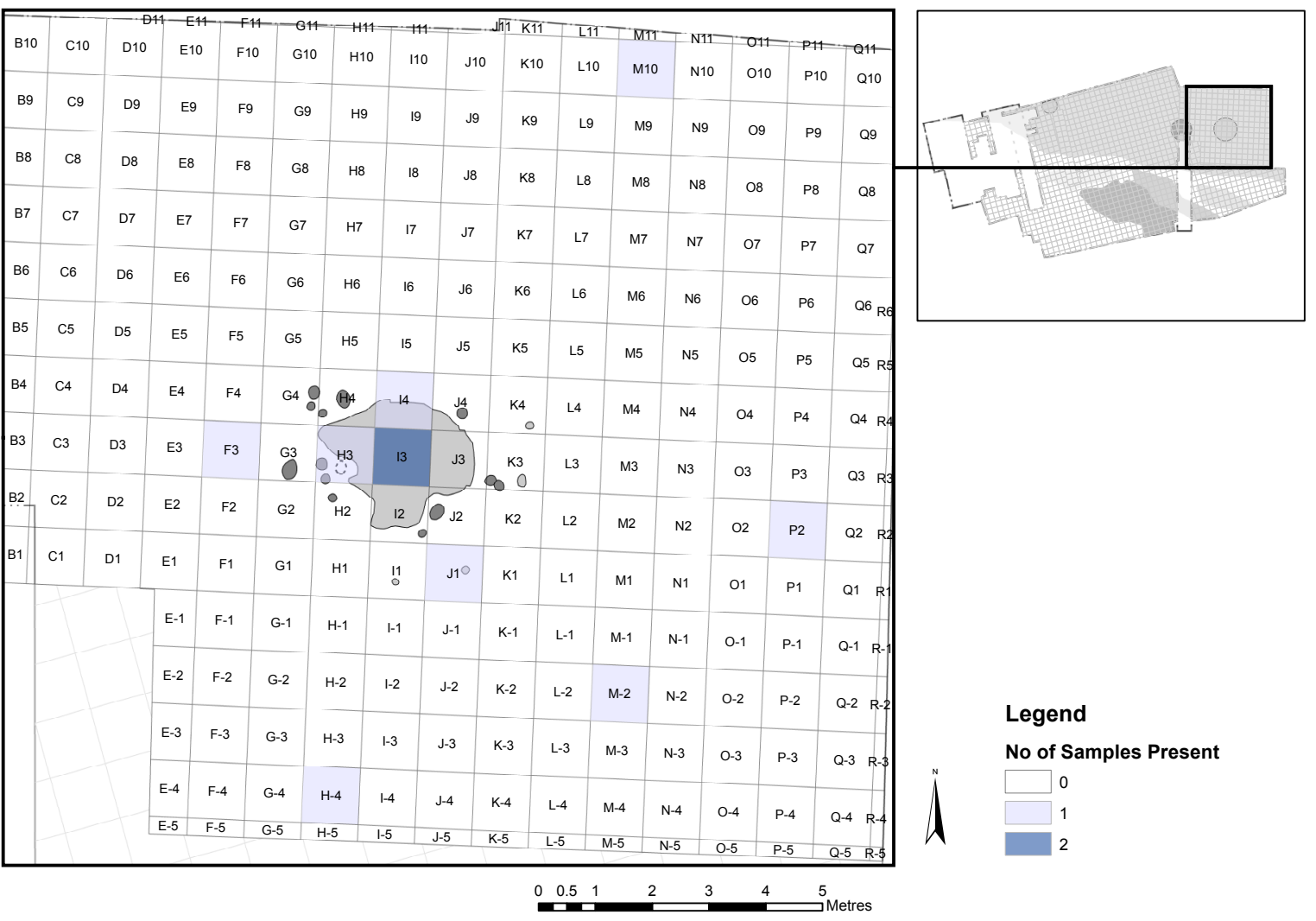

Figure 32.4: Plan showing footprint of the eastern structure and trench grid locations of archaeological soil samples (Copyright Star Carr Project, CC BY-NC 4.0). 
domestic dwellings and consequently was the most appropriate procedure to employ for the purposes of this study. To ensure provision of 30-50 g of sieved soil required to obtain sufficient phytolith concentrations from each sample, $200 \mathrm{~g}$ sub samples were obtained from 10 grid squares relative to the footprint of the dwelling. To separate the phytoliths from the soil matrix, the removal of all other soil constituents is required (Rovner 1983; Madella et al. 1998). This was accomplished using a combination of mechanical and heavy liquid separation.

Phytolith analysis relies on morphometric comparisons with modern plants and therefore the development of a botanical reference collection was necessary. Plants were selected on the basis of those which were known, through palaeoecological investigations, to be present at this locale during the Mesolithic and therefore widely available for use by the inhabitants of Star Carr. Evidence of the plant materials associated with Mesolithic dwellings recovered from European wetland and submerged sites was also considered. Reference collection phytoliths were extracted from the plant material by the process of dry ashing and were subsequently mounted onto microscope slides. The slides were viewed and photographed using an Olympus IX 71 microscope fitted with an Olympus SC100 camera linked to the digital image software programme 'Olympus, Cell Sens'.

Archaeological phytoliths extracted from the soil samples were similarly mounted onto microscope slides, viewed microscopically and photographed. Phytoliths were counted and classified according to morphological characteristics, and taxonomic specificity was determined where possible. Full silica body counts were 'normalised' and reported per gram ${ }^{-1}$ of the initial sample and patterns of distribution over the sample area were mapped based on the quantitative representation of phytolith morphotypes.

\section{Results of preliminary phytolith analysis}

Phytoliths from plants present at Star Carr during the Mesolithic were retrieved in large numbers. This in itself is a novel finding in Britain. Phytoliths from seven of 11 plant specimens represented in the reference collection were found to have satisfactory morphological matches with phytoliths from five archaeological samples. It should be noted that due to the abundance and morphotype variation of the phytoliths retrieved from all 10 archaeological soil samples, a much larger reference collection is currently being developed in order to make further morphometric comparisons and to confirm the identifications proposed here.

One of the five archaeological samples containing phytoliths with satisfactory morphological matches was taken from the periphery of the structure while the others were taken from locations outside the immediate area of the structure (morphometric comparisons between the phytoliths extracted from the archaeological samples and those of the reference collection are shown in Figures 32.5 and 32.6):

1. Common reed (Phragmites australis Cav.) stems, matched phytoliths observed in the archaeological sample from square F3, located just outside the footprint of the eastern structure. Since the natural habitat of reeds is a wetland environment, it is reasonable to suggest that reed stems were either used in constructing the structure, or deliberately brought into the structure to be utilised in some way, perhaps as flooring or bedding (Figure 32.5, A-B).

2. Phytoliths from the leaves of silver birch (Betula pendula Roth) and leaves of Galingales, which include sedges of the genus Cyperus sp., matched phytoliths in the archaeological sample from square $\mathrm{H}-4$ at the south end of the trench (Figure 32.5, C-D, E-F).

3. Phytoliths consistent with those found in the roots of compact rush (Juncus conglomeratus L.) matched phytoliths in the archaeological sample from square M-2, south-east of the structure (Figure 32.5, G-H).

4. Phytoliths from galingales leaves (Cyperus sp.) and the bark of alder (Alnus glutinosa L.) matched phytoliths in the archaeological sample from square M10 at the northern section of the trench (Figure 32.6, I-J, K-L, M-N). It should be noted that wooden artefacts made from alder wood have been found on the site (Chapter 29).

5. Phytoliths from the modern stems of bracken (Pteridium sp.) and aspen (Populus tremula L.) matched phytoliths from archaeological sample P2 at the eastern section of the trench (Figure 32.6, O-P). 

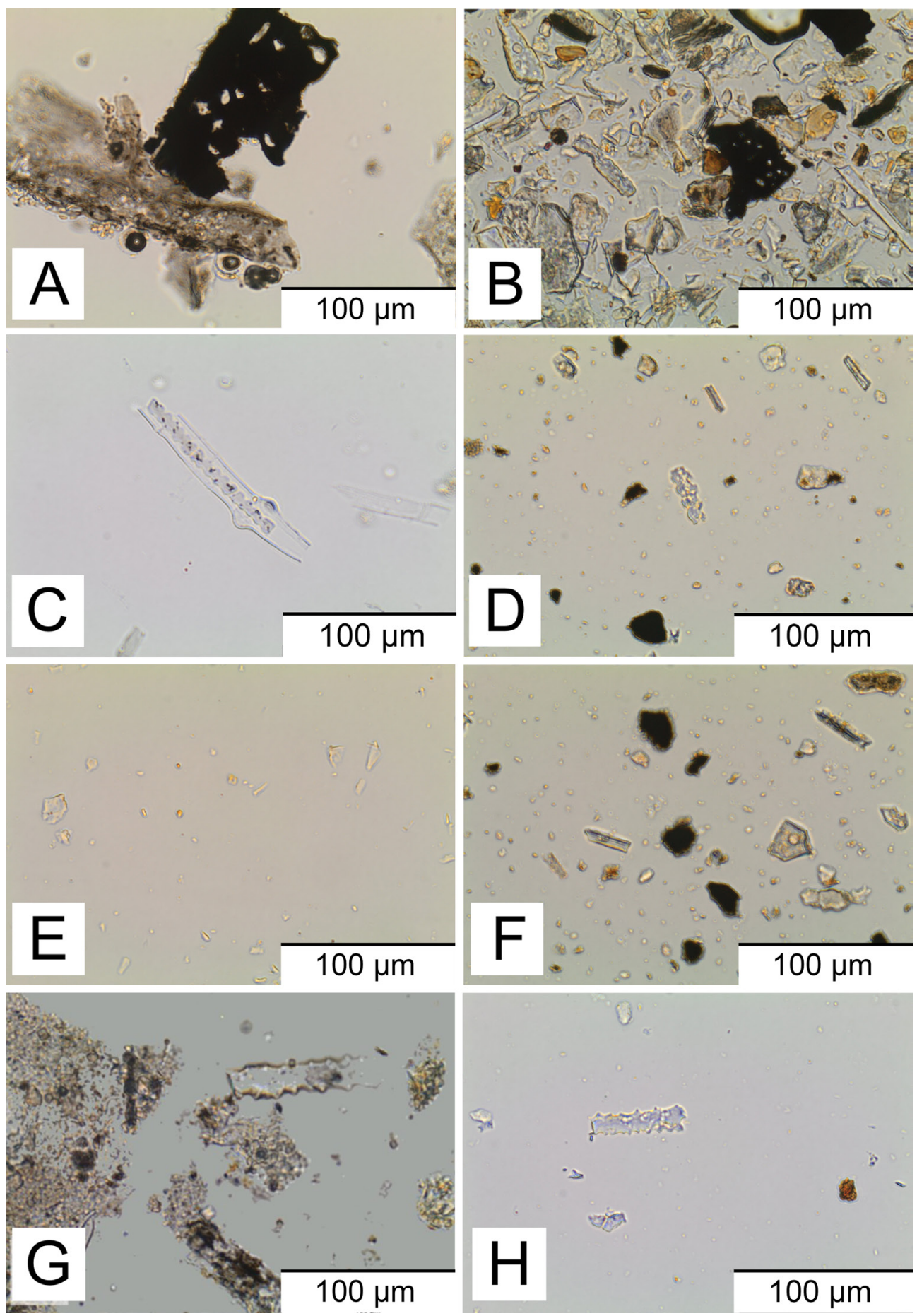

Figure 32.5: (A-H) Morphotype comparisons: phytoliths on the left represent those from the reference collection specimens and those on the right the morphotype matches from numbered archaeological samples with grid location noted.

A-B: stems from common reed Phragmites australis Cav.; sample from square F3.

C-D: leaves of galingales Cyperus sp.; sample from square $\mathrm{H}-4$.

E-F: bark from silver birch Betula pendula Roth; sample from square $\mathrm{H}-4$.

G-H: roots of the compact rush Juncus conglomeratus L.; sample from square M-2 (Copyright Alison McQuilkin, CC BY-NC 4.0). 

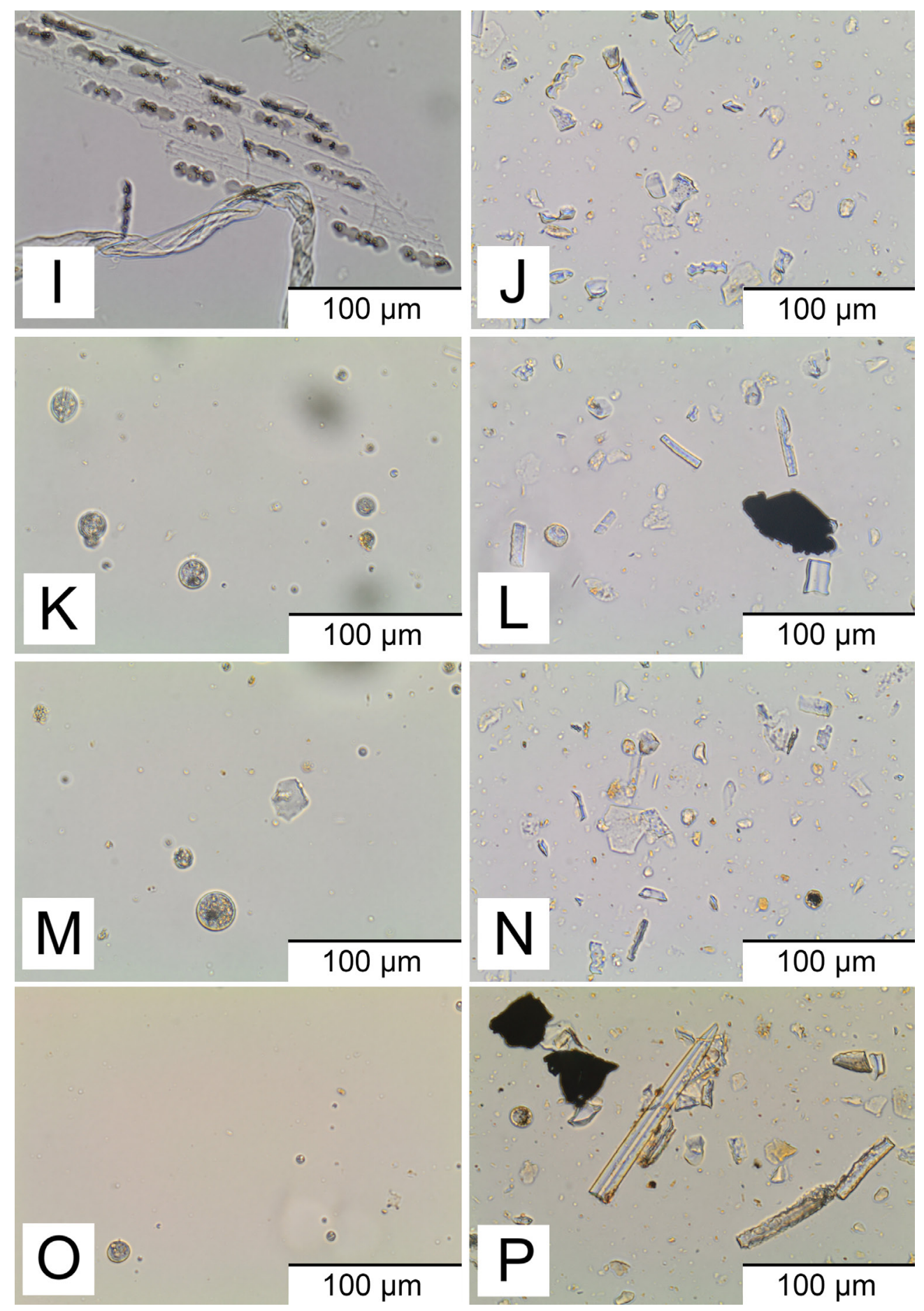

Figure 32.6: Morphotype comparisons: phytoliths on the left represent those from the reference collection specimens, and those on the right the morphotype matches from numbered archaeological samples with grid location noted.

I-J: leaves of galingales Cyperus sp.; sample from square M10.

K-L: bark from alder Alnus glutinosa L.; sample from square M10.

M-N: bark from alder Alnus glutinosa L.; sample from square M10.

O-P: stems from aspen Populus tremula L.; N: sample from square P2 (Copyright Alison McQuilkin, CC BY-NC 4.0). 
Phytoliths from each sample were tabulated and quantified into categories based on a review of descriptors relating to shape, texture and/or ornamentation (Rapp and Mulholland, 1992; Madella et al. 2010) and subsequently further grouped into categories ('long cell', 'short cell' and 'miscellaneous') in order to illustrate their relative presence (Figure 32.7). While such phytolith typologies can be found in a number of species and families of plants, it was thought that changes in their concentration may indicate a predominance of certain plants and differences in their use. It can be seen that the largest number of phytoliths come from the samples located outside the immediate area of the structure (M10 and P2). Otherwise, the samples have produced similar quantities of phytoliths.

Diatoms were also found on the site in varying proportions with the greatest numbers in squares M10 and P2 and smallest numbers within the structure. Generally diatoms live in water and moist soil, and although it is not clear why these appear on the site, they are likely to have been present in puddles/waterlogged areas (Figure 32.7).

Micro-charcoal was present across the site with a significantly large proportion in sample H-4 (Figure 32.8). The reason for this may be related to burning reeds given that it was very close to the lake edge. When this
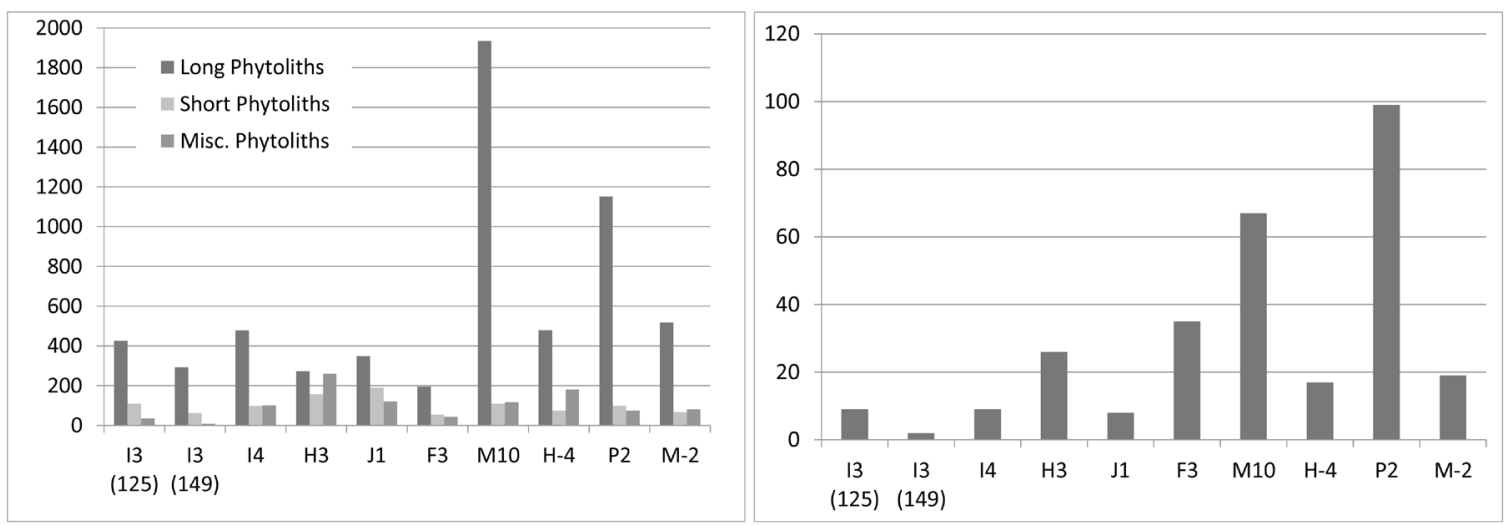

Figure 32.7: (left) numbers of long, short and miscellaneous phytoliths from each archaeological sample labelled by grid square (two contexts were sampled from inside the structure in square I3); (right) numbers of diatoms counted from each sample (Copyright Star Carr Project, CC BY-NC 4.0).
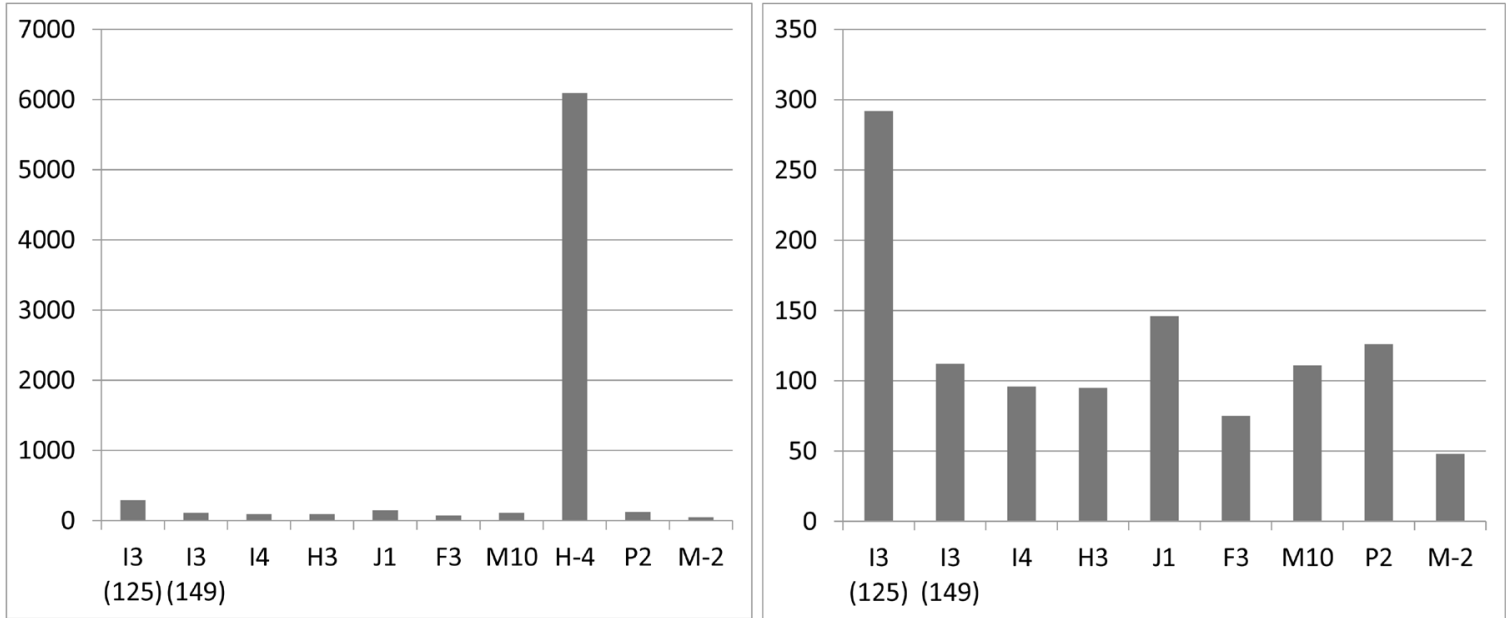

Figure 32.8: (left): bar chart showing the quantities of charcoal from each sample; (right): charcoal quantities with sample H-4 removed (Copyright Star Carr Project, CC BY-NC 4.0). 
sample is removed from the dataset, it can be seen that there was also a large proportion of charcoal from within the structure (context 125), providing further evidence for the possibility of a hearth within (see also Chapter 8).

\section{Discussion}

Despite the lack of charred seeds and fruits and the small quantity of charcoal found on site, the results obtained have provided some new insights into plant utilisation at Star Carr and particularly concerning the use of fire. The analysis of the charcoal fragments confirms the use of wood both for fuel and for clearing vegetation (Hather 1998). The micro-charcoal recovered from within the structure may also suggest the use of fire in this location.

In general, the wood taxa composition (birch and willow/poplar), the consistency of the composition with what were the most common species naturally present in the environment at this time, along with the variety of wood types from branches to trunk, illustrate that wood was chosen according to what is known as the 'minimum effort' principle' (e.g. Tusenius 1986). The following statement by Asouti and Austin $(2005,2)$ summarises this well:

'According to this hypothesis, firewood collection in the past occurred in those wooded areas situated closest to the habitation site and all species were collected in direct proportion to their occurrence in woodland vegetation'.

The presence of fungal growth in the birch wood strongly suggests that dead birch was chosen for fuel. The availability of dead birch wood is also supported by the fungal remains found on site (Chapter 31). It is useful to note that dead/rotting birch is a very useful wood for smoking meat, if the bark is first stripped off due to the high level of tannin in it (Wickham-Jones et al. 1986).

It is interesting to note that none of the species collected for fuel contain a high caloric value, meaning these species were not a particularly good fuel. The experimental work of Bishop et al. (2015) conducted on birch wood has shown that the caloric value of birch, although good, burns quickly, and works best if used as fuel combined with other species, whilst willow/poplar releases little heat, along with smoke and burns slowly. As these species were both common on site it is therefore likely that the combination of these species was opportunistic. Both birch and willow/poplar were also used to make tools as well as the wooden platforms (Chapter 6), and it is possible that the by-products derived from the initial cutting were used as firewood. Forms of management, such as coppicing the willows and poplars (Chapter 28) would provide a renewable source of wood to burn, despite its poor quality.

However, it should also be taken into account that both smoke and charcoal have uses in themselves, aside from the amount of heat produced during burning. Smoke is very useful for preserving food, preventing plants and animal material from being subject to insect and bacterial damage, curing of animal hides and also acting as an insect repellent (Groenman-van Waateringe et al. 1999; Pennacchio et al. 2010). Birch wood has a pleasant smell when burnt (Bishop et al. 2015) and its smoke would add flavour to food if used for that purpose. It is unlikely that smoking would have been carried out within the 'house' structures, but other structures may have been used, such as a lean-to of poles from which the meat hangs; the smoke can then escape and air is allowed to pass through, also drying the meat (Wickham-Jones et al 1986).

One of the most striking finds in the phytolith assemblage was that of a common reed stem taken from a dryland soil sample located on the periphery of the structure. Since the natural habitat of reeds is a wetland environment, it is reasonable to suggest that reed stems were either used in the construction of the structure or deliberately brought into the structure to be utilised in some way, perhaps as flooring or bedding. At the late Mesolithic structure found at Møllegabet II, Denmark (Skaarup 1995; Grøn 2003; Mason 2004) half the dwelling space was taken up with an earthen platform supported by cloven hazel (Corylus sp.) branches. This platform had been covered with a layer of twigs with bracken (Pteridium sp.) leaves in between and topped with sheets of bark. Beneath this, was a layer of oak (Quercus sp.) twigs, once again with bracken in between (Skaarup 1995; Grøn 2003; Mason 2004). At the Maglemosian site of Ulkestrup I, a dwelling was found to have a floor consisting of bundles of branches $250 \mathrm{~mm}$ in length and $50-60 \mathrm{~mm}$ thick. Between these bundles there were also twigs and leaves of marsh fern (Thelypteris palustris) (Grøn 2003; Mason 2004). 
Whilst it is tempting to suggest that reeds may have been used for flooring, bedding or perhaps thatching in the Star Carr structure, reeds have many possible uses which also include rope making, matting and basketry, as well as a potential food source. Clark (1954) suggested that the dried rhizomes and lower stems of reed could be mashed and ground to make an edible flour-like substance (see also Brockmann-Jerosch 1917; Dimbleby 1978; Kubiak-Martens 1999; Mears and Hillman 2007; Bigga et al. 2015; Wohler-Geske et al. 2016; Zhang et al. 2016).

\section{Conclusions}

The analysis carried out on charred plant macro-remains and phytoliths has shown that the type of plants utilised at Star Carr were consistent across the site and were dominated by the most common species present in the environment at that time. All species found have several uses, but common reeds and birch provide a great variety of plant material for crafts, building material and even food. While on the one hand the variety of remains is poor; on the other the species represented would have been sufficient to supply plant material for almost all aspects of the daily lives of the Mesolithic inhabitants. Finally, the retrieval of vast numbers of phytoliths from the Mesolithic plants at Star Carr is in itself a novel finding in Britain, clearly illustrating the potential of utilising this method for accessing beneficial palaeoethnobotanical information. In order to broaden current capabilities for using phytolithology for plant identification and to enhance our ability to confirm findings on archaeological sites across the UK in future, a large British botanical phytolith reference collection is presently under development. 